\title{
Karahanlı Türkçesi Metinlerinde Kadınlarla İlgili Kelime ve Kalıp İfadeler
}

\section{Words and Pattern Phrases Related to Women in Karakhanid Turkish Texts}

Aslı Zengin $^{1}$ (1)

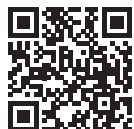

'İstanbul Üniversitesi, Edebiyat Fakültesi, Türk Dili ve Edebiyatı Bölümü, İstanbul, Türkiye

ORCID: A.Z. 0000-0002-0892-9880

Sorumlu yazar/Corresponding author: Aslı Zengin,

İstanbul Üniversitesi, Edebiyat Fakültesi, Türk Dili ve Edebiyatı Bölümü, İstanbul, Türkiye

E-mail: asluygun@istanbul.edu.tr

Başvuru/Submitted: 26.09.2021

Revizyon Talebi/Revision Requested: 24.11.2021 Son Revizyon/Last Revision Received: 29.11.2021 Kabul/Accepted: 22.12.2021

Online Yayın/Published Online: 27.12.2021

Atıf/Citation:

Zengin, A. (2021). Karahanlı Türkçesi metinlerinde kadınlarla ilgili kelime ve kalıp ifadeler. TUDED, 61(2), 763-786.

https://doi.org/10.26650/TUDED2021-1001065

\section{ÖZET}

Karahanlı Türkçesi, Türklerin coğrafî, kültürel, ekonomik, sosyolojik ve inanç çerçevesinde İslamileşmeye başladıkları bir dil devresini temsil eder. Bu döneme ait olan dil yadigârlarımız Kutadgu Bilig, Dîvânu Lugâti t-Türk, Atebetü'l-Hakâyık ile Kur'an Tercümelerinden ibarettir. Söz konusu eserlerde kadın ile ilgili kavram alanı, kadınlar için kullanılan adlandırmalar çerçevesinde değerlendirilmeye çalışılacaktır. Kadınlarla ilgili bu yeni muhitte ortaya çıkan adlandırmaları eserler bağlamında ele alınıp incelenecektir. İslamiyet'in kabulünden önce toplum içerisinde önemli bir yere sahip olan kadının İslami devirden itibaren konumunu gösteren söz varlığını ortaya koymak amaçlanmaktadır. Bu noktada "kadın”ın doğuştan gelen ve sonradan kazandığı adlara yer verilecektir. Çalışmada gerekli görülen kelimelerin Eski Türkçedeki şekilleri ve kullanım alanları hakkında da bilgi verilmeye çalışılacaktır. Bu sayede öteden beri kullanılan kelimelere yeni kelimelerin ilave edilip edilmediği de görülecektir. Ayrıca anlam bakımından farklılaşma yaşayan kelimeler de tespit edilmeye çalışılacaktır.

Tespit edilen kelimeler, eserler arasında mukayeseli bir şekilde ele alınıp incelenecek ve dönemin "kadın" adlandırmaları açısından bir kanaate varılmaya çalışılacaktır.

Anahtar Kelimeler: Kadın, Karahanlı Türkçesi, Kutadgu Bilig, Dîvânu Lugâti’tTürk, Atebetü'l-Hakâyık, Kur'an Tercümeleri

\section{ABSTRACT}

Karakhanid Turkish is an expression that represents a language period in which the Turks began to "differentiate" within the framework of geographical, cultural, economic, sociological, and religious beliefs. Language heirlooms belonging to this period consist of the Kutadgu Bilig, Dîvânu Lugâti't-Türk, Atebetü'l-Hakâyık, and Qur'an Translations. This study examines the concept of women found in these works and evaluates these concepts within the framework of the nomenclature used for women.

Women have always stood out in the pre-Islamic Turkish state and society. This study presents the vocabulary that shows the position of women as having a crucial place in society before the adoption of Islam. The congenital and acquired names of "woman" will be included. Furthermore, the study also provides information about the forms and usage of these words in the Old Turkish period. It will be determined if new words have been added since then and if there are words that differ in meaning.

The identified words - names given to women during the Karakhanid Turkish period - will be examined and analyzed comparatively among the ancient works.

Keywords: Woman, Karakhanid Turkish, Kutadgu Bilig, Dîvânu Lugâti't-Türk, Atebetü'l-Hakâyık, Qur'an Translations 


\section{EXTENDED ABSTRACT}

Women are one of the basic building blocks of Turkish society. Thus, the place of women in Turkish society has always been respected. In the Kultigin Monument, one of the Göktürk Monuments - which is the oldest known source of Turkic script - the name of the khan's wife, İlbilge Qatun in the Second Göktürk State, is among the people created by God so that the Turkish nation would not perish. This situation, which shows the political position of women in the old Turkish state tradition, indicates the value given to women in Turkish society (Tellioğlu, 2016, s. 219). An illustration of the position of women may be found in the expression, "God raised my father İl-teriş Kağan and my mother İl-bilge Qatun so that the Turkish nation would not perish," found in the Bilge Kağan Monument, demonstrating the high political and social value of women in Turkish culture (Kafesoğlu, 2015, s. 141). Women had an important place in society during this period. The decrees were jointly signed by the khan and his wife. The khan's wife took the helm with the ceremony and ruled the state jointly with the khan. In addition, we understand from the documents of that period that women participated in the state administration (Taşağıl, 2017, s. 184). There are various evidences in the written sources of the old Turkish society about women's acquired status and the status bestowed on them. One of Oğuz Kağan's wives was born from a blue light, and the other, as a woman with extraordinary features, was born from a sacred tree. This holiness was an innate holiness bestowed upon the wives of Oğuz Kağan.

Women had almost the same rights as the khan before Islam and did not lose these rights after the adoption of Islam, as can be seen from ancient scripts. The works that have survived from Karakhanid Turkish are the Kutadgu Bilig, Dîvânu Lugâti 't-Türk, Atebetü'l-Hakâyı, and Qur'an Translations. This study examines the concept of women found in these works and evaluates the concept within the framework of the nomenclature used for women.

In this paper, a classification is used for the namings that women have had from birth and the namings they acquired later. In the classification, the words expressing the natural and acquired status of women used in the texts are grouped under the following headings:

1. Innate (Endowed) Statuses

1.1. Gender-Based Naming

1.2. Age-Based Naming

1.3. Kinsfolk-Based Naming

1.4. Nomenclature Based On Blood Kinship

2. Statuses Acquired

2.1. Nomenclature Based on Marriage

2.2. Social Classes

2.3. Titles, Ranks 


\subsection{Names of Women Showing Moral Inappropriateness}

\subsection{Names of Women Who Are Physically and Spiritually Clean}

The names given to women are classified according to the nomenclature determined under these headings. Explanations about words are provided if deemed necessary. If words have acquired new meanings from the Old Turkic to Middle Turkic periods, these are also indicated. While this study reveals the vocabulary related to the concept of woman, it also presents this vocabulary to the different disciplines.

From the works that were the subject of the research, forty-four (44) names given to women were identified. In addition, it was found that the same words may have different meanings. Consequently, the expanding vocabulary in terms of meaning was one of the important outputs of the study as well. 


\section{GíRIŞ}

Orta Türkçenin ilk evresini teşkil eden Karahanlı Türkçesi dil devresi, aynı zamanda Türk toplumunun da yeni bir medeniyetin eşiğinde bulunduğu bir evredir. Medeniyetin ayrılmaz parçası olan dil, bu dönemde İslâmiyet' in tesiriyle Arapça ve Farsça söz varlığını yavaş yavaş bünyesine almaya başlar. Dilde ve medeniyette yaşanan tekâmül, kadının adlandırılması bağlamında da hiç şüphesiz hissedilecektir. İslamiyet’ten önce Türk toplumu içerisinde mühim bir yere sahip olan kadın, İslamiyet'in kabulüyle beraber sosyal ve siyasi anlamda daha da mühim yerlere gelmiştir.

Bilinen en eski Türkçe kaynak olan Göktürk Abideleri'nden Kültigin Abidesi'nde, Tanrı'nın Türk milleti yok olmasın diye yarattığı kişiler arasında İkinci Göktürk Devletinde, kağanın eşi İlbilge Hatun'un adına yer verilmiştir. Eski Türk devlet geleneğinde kadının siyasi konumu gösteren bu durum, Türk toplumunda kadına verilen değerin bir ifadesi olarak değerlendirilmiştir (Tellioğlu, 2006, s. 219). Bilge Kağan Abidesi'nde “Tanrı Türk milleti yok olmasın diye babam İl-teriş Kağan ile anam İl-bilge Hatun’u yükseltti” ifadesi, Türk kültüründe kadının siyasi ve toplumsal değerinin ne kadar yüksek olduğunu göstermektedir (Kafesoğlu, 1977, s. 249). Emirnameler, kağan ve karısı tarafından onaylanırdı. Kağanın karısı, düzenlenen tören ile başa geçer ve devleti kağan ile birlikte ortak bir şekilde yönetirlerdi. Devlet yönetiminde hatunların da söz sahibi olduğunu o döneme ait vesikalardan anlıyoruz (Taşağıl, 2017, s. 184). Elbette sadece sonradan kazandıkları adlandırmalar değil, doğuştan gelen adlandırmalar noktasında da eski Türk toplumunun yazılı kaynaklarında çeşitli veriler bulunmaktadır. Bir destan metni olmakla ve gerçeği birebir yansıtmamakla beraber Oğuz Kağan Destanında anlatılan olguya göre Oğuz Kağan'ın eşlerinden biri mavi bir ışıktan, diğeri kutsal bir ağaçtan doğmuş olağanüstü özelliklere sahip kadınlardır ve bu kutsiyet doğuştan gelen, Oğuz Kağan'ın eşlerine bahşedilmiş bir kutsiyettir.

Karahanlı Türkçesinden günümüze ulaşan eserler, Kutadgu Bilig, Dîvânu Lugâti 't-Türk, Atebetü'l-Hakâyık ve Kur 'an Tercümeleri'dir. Bu bağlamdan hareketle Karahanlı Türkçesi ile yazılmış metinlerde kadın kavram alanı, adlandırmalar ve kalıp ifadeler bakımından doğuştan gelen (bahşedilmiş) ve sonradan kazanılmış olanlar olarak iki açıdan ele alınıp değerlendirilecektir.

Bu eserlerin kelime kadrosu incelendiğinde tamamıyla Karahanlı Türkçesi yazı diline ait kelimeler bulunduğunu ifade etmek doğru olmayacaktır. Özellikle Dîvânu Lugâti 't-Türk'te madde başı olan hatırı sayılır miktarda kelimenin diğer Türk boylarına ait olduğunu bizzat Kaşgarlı Mahmud ifade etmiştir. Bununla beraber gerek devrin ortak yazı dilinin Karahanlı Türkçesi olması, gerekse sözü edilen dönemde bu kelimelerin var ve kullanılır olduğunun bilinmesi, çalışmamız kapsamına almamıza neden olmuştur. Bunlar ilgili kelimenin açıklama kısmında belirtilmiştir. 


\section{YÖNTEM}

Karahanlı Türkçesine ait bahsi geçen eserler, kadın ve kadına ait sözler kapsamında taranarak ilgili söz varlığı çıkarılacaktır. Bu söz varlığının Karahanlı Türkçesi döneminde sahip olduğu anlamlar, semantik bağlam ve metin dizini yardımı ile verilecektir. Kelimelerin daha sonraki ve mevcut metinlerde karşılaşılmış ise daha önceki dönemlerde ifade ettiği manalar ortaya konularak uğradığ 1 değişiklikler belirlenecektir. Gerekli görülen kelimeler üzerinde günümüz Türk lehçelerindeki kullanılırlık durumu araştırılarak bu kelimelerin varlığını sürdürüp sürdürmediği tespit edilmeye çalışılacaktır.

\section{Doğuştan Gelen (Bahşedilmiş) Adlandırmalar}

Doğuştan gelen adlandırmalar; cinsiyet, akrabalık, yaş, ölüm ve sosyal sınıflardır. Bu göstergeler üzerinde kişinin herhangi bir etkisi yoktur.

\subsection{Cinsiyete Dayalı Adlandırma}

Sıradan bir kadının yani doğrudan cinsiyet bağlamında adlandırılmaları incelenen metinlerde şu şekildedir:

ewçi: Kadın 4496 (KB)

"Ev, çadır" anlamına gelen $e b$ kelimesinin $+c ̧ i$ isimden isim yapma ekini almasıyla ortaya çıkan bu kelime “(evde oturan, ev işlerini yapan) kadın” anlamlarına gelmektedir.

Kutadgu Bilig'de "kadın” karşılığında kullanılan kelime, "kadın, eş" anlamında Yenisey Yazıtları'nda da karşımıza çıkmaktadır: ebçime, begime bökmedim, adırıldım "Eşime, beyime doyamadım, [onlardan] ayrıldım” (E 109, 3).

urug̉lug tarı̈glıg bedükler tili

bedükrek bolur bolma ewçi ḳulı (KB 4496)

“Soyu sopu büyük olanlar yüksekten konuşur; sen kadın esiri olma.”

ewlik ewlük: Kadın C59, 4475, 4486, 4487, 4491, 4607 (KB); 131/115 (DLT)

"Kadın” anlamında karşımıza çıkan bir diğer kelime de ewlük kelimesidir. Ew "ev" isim kökü ile $+l i k /+l u ̈ k$ isimden isim yapma ekinden müteşekkil olan bu kelime yine "kadının eve yaraşır” olması anlamıyla ilişkilendirilebilir.

biregü bay $\boldsymbol{e w l i k}$ tiler üstikip

takı biri körklüg tiler köz tikip (KB 4487)

“Biri zengin kadınla evlenmek ister; biri güzel olmasını ister ve ona göz diker." 
Tünle bultt örtense ewlük urı keldürmiş̧̧e bolu.r tayda bultt örtense ewkw yagl kirmişçe bolu.r. Anlamı: "Geceleyin bulutlar kızarırsa; kadın, erkek çocuk doğurmuş gibi olur. Sabahleyin yanarsa, saldıran düşman eve girmiş gibi olur.” (131/115 DLT)

işi: Kadın 5080 (KB); işler eşler eşiler: Kadın, kadınlardan hanım olan 52/37, 64/51, 71/58 73/59, 87/79, 90/81 (DLT); 30/80b1=16:92 (R)

İşi eşiler eşler işler eşler Göktürk Abideleri’nden itibaren eşi şeklinde karşımıza çıkan bir kelimedir: ėşilik k’ ız ogllin küng boltı (KT. D7) "hanımefendiliğe yakışır kız evlatları cariye oldu" Kelimenin okunuşu ve anlamlandırılışı üzerinde çokça tartışma bulunmaktadır Kelime, ilk olarak Karamanlıoğlu tarafından yayımlanan bir makalede eşilik "prenses olacak, bey hanımı olmaya layık” şeklinde anlamlandırılmıştır (Karamanlıoğlu, 1966, s. 320-322).

Röhrborn, beg ve işi kelimelerinin Uygurcada birlikte geçtiği örnekleri incelemiş ve işi kelimesine "kadın, hanım" anlamını verdikten sonra beg işi ikilemesini "kral ve kraliçe/han ve hatun”, "hükümdarın arkadaşları", "hükümdar ve onun maiyeti”, "hükümdar ve (hükümdarın) takipçileri” şeklinde anlamlandırmıştır (Kaya 2018: 21).

Kelime, Kutadgu Bilig'de işi şeklinde sadece 5080. beyitte geçer:

tilin sözlemiş sözde yanmaz eren

sözinde yanığlı işiler sanı (KB 5080)

“Erkek verdiği sözden geri dönmez; sözünden dönenleri sen kadın bil.”

Kutadgu Bilig'de işi kelimesinin küçültücü, yerici bir anlamda kullanıldığı görülmektedir.

Kelime Dîvânu Lugâti 't-Türk’te eşi olarak geçmektedir. Kelimenin karşısında şöyle bir açıklama bulunmaktadır: "eşle.r kadın. Aslı eşi.le.r'dir. Kadınlardan hanım olanlar demektir. Çok kullanıldığı için hafifletmek maksadıyla ye (ى) düşürülmüştür. Çokluktur, teklik yerine kullanılır" (DLT 71/58).

Kelime Türkçe Illk Kur'an Tercümesi'nde (Rylands Nüshası) bir yerde geçmektedir:

Bolmaylar ol işler teg kim buzdı egirmiş yipini (30/80b1=16:92 R)

"Ĕ̈irdiği ipini harap eden o kadınlar gibi olmayınız."

Clauson, kelimenin, é:ş “eş” sözüne üçüncü teklik şahıs iyelik eki ilavesiyle oluştuğunu düşünmektedir (Clauson 1972, 256a). Röhrborn da aynı kanaattedir. Kelime, $\bar{l} s ̧ \bar{l}$ “soylu kadınlar için bir unvan" biçiminde Farsçaya da geçmiştir (Röhrborn 2019: 91).

1 Detaylı bilgi için bkz. (Emine Gürbüz, Türkiye'de Yapılan Çalışmalarda Orhon Yazıtları'nı Okuma ve Yorumlama Farklılıkları, Yayımlanmamış Yüksek Lisans Tezi, İstanbul, Yıldız Teknik Üniversitesi Sosyal Bilimler Enstitüsü, 2020). 
kısır: Kısır kadın ve kısır hayvan. 183/156, 481/385 (DLT)

Kelime yalnız kadın için kullanılmamakla beraber, “çocuk sahibi olamayan kadın” anlamında incelenen metinlerden sadece Dîvânu Lugâti 't-Türk'te karşımıza çıkmaktadır.

kız: K1z (bint), kadın. C59, 75, 77, 399, 400, 564, 565, 866, 869, 1163, 1164, 1165, 1166, $1225,1226,1247,1486,1495,2278,2280,2380,2403,4418,5291,5827,6122,6385,6267$, 6491 (KB); 125/110, 164/142, 222/191, 588/482 (DLT); 33/21a1=33:59, 32/18a3=28:27, $38 / 92 \mathrm{a} 2=66: 5,38 / 98 \mathrm{~b} 3=66: 12(\mathrm{R}) ; 34 \mathrm{v} / 4=002 / 266,58 \mathrm{v} / 9=004 / 009,59 \mathrm{r} / 5=004 / 011$, $59 \mathrm{r} / 6=004 / 011,227 \mathrm{v} / 4=018 / 077,228 \mathrm{r} / 4=019 / 091,210 \mathrm{v} / 8=017 / 062,169 \mathrm{v} / 4=011 / 079$, $185 \mathrm{v} / 4=013 / 023$ (TİEM)

Ayġil cüftlerine hem kızlarıya (33/21a1=33:59 R)

"Eşlerine hem kızlarina söyle."

hız: Halaçlardan bir tabakanın ağzında kız 541/442 (DLT)

Dîvânu Lugâti 't-Türk, XI. asrın lehçeleri hakkında yegâne bilgi sahibi olduğumuz kaynaktır. Oğuzlar ve Kıpçaklar bazen kaf'ı hı'ya dönüştürebilirler. Bunlar Halaçlardan bir tabakadır. xızım derler "kızım" demektir.

ev kızı: "Bakire kız”a ev kızı denir; evde kalan (kocaya gitmemiş kız) demektir. 164/142 (DLT)

kapaglıg k1z: bakire k1z 248/218 (DLT)

Her iki kalıp ifade de incelemeye konu olan metinlerden sadece Dîvânu Lugâti 't-Türk'te geçmektedir.

yinçge kız: odalık k1z. 164/142, 610/503, 637/533 (DLT); 61v/3=004/025 (TİEM)

Bu kalıp ifade Dîvânu Lugâti 't-Türk'te ve Karahanlı Türkçesi Satır Arası Kur'an Tercümesi'nde (TIEM Nüshası) geçmektedir. Gerek kapaglıg kız gerek yinçge kız kelimeleri $k ı z$ kelimesinin "cariye" manasına da gelmesi dolayısıyla ayırt edici birtakım sıfatlarla bezenip ayrı bir yerde konumlandırıldığına örnektir. Her iki kelime grubu da mecazen "genç, cariye kızlar" için kullanılmıştır.

kızkıya: Küçük kız 519/418 (DLT)

$K ı z$ ismine $+k \imath y a$ küçültme fonksiyonunda isimden isim yapma ekinin eklenmesiyle oluşmuş olan kelime sadece Dîvânu Lugâti 't-Türk'te karşımıza çıkmaktadır:

kızkıya (519/418 DLT) “benim kızcağızım”

Kaşgarlı, eserinde “İsimlere Yapılan Ziyadeler” başlığı ile meydana getirdiği bölümde elif, 
$v a v$ ve ye harflerinin yumuşatma ve uzatma görevleri ile kullanıldığını ifade eder. Buna bağlı olarak örneğin Dankoff-Kelly yayınında "kız" kelimesi “qiz” biçiminde, i'li olarak okunmuştur (Dankoff-Kelly: 1985). Fikret Turan, Kaşgarlı’nın Uygur bölgesinden olduğunu ve bu bölgede /1/ sesinin genelde /i/ ile karşılandığını belirtir. Ancak bunun yanında eserin tek nüshasının teliften 200 y1l sonraya ait olması ve üzerine sonradan harekeler eklenmesi sebebiyle ünlü sisteminin net biçimde ortaya konulamadığına da dikkat çeker (Turan 2008-2009: 119) ve /1/ ünlüsünün Türkçenin aslî seslerinden biri olduğunu söyler ((Turan 2008-2009: 128)

tişi: Dişi, kadın 979, 3574, 3581, 3583, 3584, 3608, 4132, 4498, 4500, 4503, 4519 (KB); 88, 273 (AH); 26/85b2=4:127, 28/11b3=7:127, 26/80a3=4:117 (R); 21r $/ 1=002 / 178,41 \mathrm{v} / 3=003 / 036$, $41 \mathrm{v} / 4=003 / 036,59 \mathrm{v} / 5=004 / 012,79 \mathrm{r} / 4=004 / 176,317 \mathrm{v} / 4=035 / 011,352 \mathrm{v} / 3=041 / 047$, $388 \mathrm{v} / 2=053 / 021(\mathrm{TI} E M)$

Tişi kelimesi “dişi, kadın” anlamıyla Kutadgu Bilig'de, Atebetü’l-Hakayık'da, Türkçe Ilk Kur'an Tercümesi'nde (Rylands Nüshası) ve Karahanlı Türkçesi Satır Arası Kur'an Tercümesi'nde (TIEM Nüshası) geçmektedir.

Ol kim oḳıyur sizị üze bitig içinde atasız tişiler içinde (26/85b2=4:127 R)

"O ki sizin üzerinize babasız kadınlar içinde Kur'an okur."

Dîvânu Lugâti 't-Türk'te ise "dişi, her şeyin dişisi” anlamında tışı kelimesi bulunmaktadır: 200/171, 201/172, 264/230 (DLT)

tişilig: Dişi 61r/8=004/024, 307r/4=033/037 (TİEM)

Dişi anlamında tişilig kelimesi Karahanlı Türkçesi Satır Arası Kur 'an Tercümesi’nde (TIEEM Nüshası) karşımıza çıkmaktadır.

uragut: Kadın, kız, dişi 26/1b1=4:24, 26/11a1=4:34, 26/85a3=4:127 (R); 203r/1=016/092, $29 \mathrm{v} / 1=002 / 235,413 \mathrm{v} / 5=065 / 004,413 \mathrm{r} / 4=065 / 006,254 \mathrm{r} / 8=024 / 004,407 \mathrm{v} / 2=060 / 012$, $400 \mathrm{v} / 2=058 / 001,413 \mathrm{v} / 5=065 / 004$ (TIEM), 36/2b2=41:47 (R)

Alı̄ āzād tişiler urag̀utlardın (26/1b1=4:24 R)

"Kadınlardan azad olanları alın."

Yük kötürmez híç urag̉ut ḳoḍmaz (36/2b2=41:47 R)

"Hiç yük götürmez, kadın bırakmaz."

Eski Türkçede toplumsal cinsiyet bağlamında kadının adlandırılmasında daha ziyade katun, tişi, uragut, eşi, èbçi, uzun tonlug, vb. kelimeler kullanılmıştır. Karahanlı Türkçesi metinlerinde "kadın" kelimesi karşılığında işi işler eşler eşiler, ewçi, ewlik, kız, tişi, uragut kelimelerinin kullanıldığı tespit edilmiştir. Kadınların isimlendirilmesinde kendilerinden beklentiler hakkında edindiğimiz ipuçları kadının ewçi ve ewlik ewlük olmalarıdır. Yani 
“ev işleriyle uğraşan, eve yaraşan” anlamları kadından beklenen temel beklentilerden birini göstermektedir. Kelimelerin sahip olduğu anlamlar, devrin anlayışı ile de örtüşmektedir. Kutadgu Bilig'de kadınlar hane içinde konumlandırılması ve eğitilmesi düşünülen, içkili eğlence meclislerinden uzak tutulması gereken bir varlık olarak gösterilmiştir (Demir 2021: 206). Yine evlenmemiş, bekâr kızlar için de çeşitli adlandırmalar bulunmaktadır. Bunlar ev kızı, kìz, kapaglıg kız, yinçge kız kelimeleridir. Bu kelimeler Türk toplumunun öteden beri sadece kız kelimesiyle yetinmeyip onu türlü kelimelerle tavsif etmek suretiyle süsledikleri ve kızların bekâr olma durumlarını ön plana çıkardıklarının göstergesidir.

\subsection{Yaşa Dayalı Adlandırma}

açı: Barsgan lehçesinde ihtiyar kadın. 56/42 (DLT)

Dîvânu Lugâti 't-Türk, Kâşgarî'nin Türk toplulukları coğrafyasında yaptığg gezi ve araştırmalarda elde ettiği verilere dayalı oluşturulduğu ve içinde ayrıntılı gramer bilgileri de sunulan geniş hacimli Türk lehçeleri sözlüğü ve dil kültürü ansiklopedisidir (Turan, 20082009, s. 118). Dolayısıyla Dîvânu Lugâti 't-Türk'ten kadın kavram alanıyla ilgili elde edilen dil malzemesi çeşitli diyalektlerde kullanılan malzemeleri de ihtiva etmektedir.

kurtga: ihtiyar kadın, çok yaşlı kadın 399, 1547, 3541 (KB); 588/460 (DLT); 34/37a3=37:135, $37 / 89 \mathrm{a} 1=51: 29(\mathrm{R}) ; 169 \mathrm{r} / 6=011 / 072,260 \mathrm{r} / 5=024 / 060,384 \mathrm{v} / 8=051 / 029,272 \mathrm{v} / 8=026 / 171$, $328 \mathrm{r} / 3=037 / 135$ (TİEM)

Yaşa dayalı olarak kadının adlandırılmasında "yaşı kadın" anlamında açı ve kurtga kelimeleriyle karşılaşıyoruz. Bunlardan açı kelimesi hakkında Kaşgarlı, babasının doğum yeri olan ve iyi bildiğini düşündüğümüz "Barsgan lehçesinde" diyerek, döneme ait bir lehçe bilgisi de vermiştir (56/42 DLT).

Eski Uygur Türkçesinde yaşlag, yaşlıg, ķarı, harı, ķarig, abuçķa “ihtiyar kadın” anlamında kullanılmıştır (Caferoğlu, 1993). Kurtga kelimesinin Eski Uygur Türkçesinde "yaşlı, ihtiyar" anlamı görülmekteyken, Karahanlı Türkçesi metinlerinde kelime "kocakarı, çok yaşlı kadın" anlamı kazanmıştır.

\subsection{Soya Dayalı Adlandırma}

Kadınların ailelerinin soylu olmalarına bağlı olarak doğuştan kazandıkları adlandırmaları incelenen metinlerde şu şekildedir:

tarım: Tiginlere, Afrâsiyab'ın soyundan gelen, küçük olsun büyük olsun bütün hatunlara hitap edilirken kullanılan söz 199/170 (DLT)

A. Caferoğlu tarafından "kadınlara mahsus bir unvan" olarak kabul edilebilen bu tabiri, S. Çağatay terim şeklinde okumaktadır (Çağatay, 1978 s. 320). P. Pelliot ise terimin eski Türkçede “prenses” manasına gelen tengrimden türediği düşüncesindedir (Donuk, 1988, s. 49). 
katun: Hatun; Afrâsiyab soyundan gelen bütün kadınların unvanı 81/71, 189/161, 206/177 (DLT)

ogla.gu kātun (81/71 DLT)

oglagu katun: Hatun, hanedana mensup kadın (Bolluk içinde yetiştiği için böyle denir.) 81/71 (DLT)

Göktürk Abideleri’nden itibaren karşımıza çıkan katun kelimesinin bilhassa Dîvânu Lugâti 'tTürk’te aynı şekilde unvan olarak kullanıldığı görülmektedir.

um(a)y teg ög(ü)m k(a)tun kuut(ı)ña in(i)m kül tig(i)n (e)r at bultı (K.T. D. 31) "Umay misali annem Hatun'un kutu sayesinde, kardeşim Kül Tigin erkeklik adını elde etti.” (Tekin, 2014 s. 32-33)

katun yok bolmış erti (T. K. 7) "Hatun ölmüş idi.” (Aydın, 2020, s. 183)

Yazıtlarda "hatun, kağan hanımı" anlamında geçen katun kelimesinin kökeni ile alakalı olarak ortaya atılan çeşitli görüşler bulunmaktadır: Tenişev’e göre kelime kat- fiil köküne fiilden isim yapma -un ekinin getirilmesi ile yapılmıştır. Levitskaya'ya göre “kat- fiil kökü Eski Türkçede ve çağdaş Türk dillerinde "katmak, eklemek, koymak" anlamlarına gelmektedir. Demek ki katun kelimesi "katılmış, eklenmiş, dâhil edilmiş" demektir. Kat- fiil kökünden başka da akrabalık kelimeleri yapılmaktadır" (Nurdin Useev, 2012, s. 63). S. Çağatay, "qat” kelimesinin "xatun"dan "qadın” şekline dönüşen ismin kısaltması olduğunu düşünmektedir. Bu görüşe katılmayan Peter Zieme kelimenin kökeninin “eş” anlamındaki qat kelimesi olduğunu belirtir (Peter Zieme, 2013, s. 132). Tuncer Gülensoy, kayın kelimesinde olduğu gibi katun kelimesinin kökünde de akrabalık bildiren ka'nın bulunduğunu, katun kelimesinin bu kökle tun ekinin birleşmesinden meydana geldiğini belirtir (Gülensoy, 2007, s. 405). Räsänen'e göre

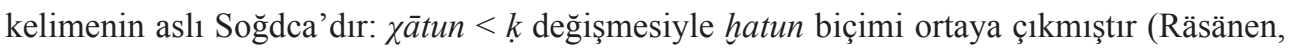
1969, s. 157).

Türk devletlerinde kağan'dan sonra ikinci sırayı katun almaktadır. Katunlar, kağanlar gibi töre ile katunluk makamına oturuyorlar, kağanla beraber idarede bulunuyorlardı ki Kül Tigin ve Bilge Kăgan yazıtlarında geçen; Türk Budun yok bolmazun tiyin, bodun bolçun tiyin kangım İl-teriş Kaganıg, ögüm İl-Bilge katunı töpüsinte tutıp yügerü kötürmiş erinç. "Türk Milleti yok olması diye millet olsun diye babam İltiriş Kăganı, annem İlbilge Hatunu göğün tepesinde tutarak yukarı kaldırmış olacak." cümlesi bunu çok güzel açıklamaktadır (Saadettin Gömeç 2009: 220). Bununla birlikte yalnız Türk soyundan gelen hatunların çocukları veliaht olabiliyorlard1. Kağan öldüğü zaman, yerine geçecek olan çocuğu küçük ise, o vakit katunun devleti oğlu adına yönetildiğini de görüyoruz. Geniş bir kullanım sahası olan katun kelimesi bazı lehçelerde saygı ve şerefi ifade eden eski manasını korumuştur (Çağatay 1962: 13). 


\subsection{Kan Akrabalığına Dayalı Adlandırma}

Aralarında kan bağı olan akrabalardan dişi olanların adlandırılışı incelenen metinlerde şu şekilde tespit edilmiştir:

ana: Anne 37, 41, 652, 873, 1219, 1387, 1486, 3784, 5768 (KB); 27/12, 59/45, 538/439 (DLT); 291 (AH); 30/71a3=16:78, 28/28a2=7:150, 31/66a3=20:94 (R) ; 29r/2=002/233, $58 \mathrm{v} / 5=004 / 007,55 \mathrm{v} / 5=004 / 007,62 \mathrm{v} / 2=004 / 033,74 \mathrm{r} / 9=004 / 135,24 \mathrm{v} / 5=022 / 005$ (TIEM)

Tayrı çıḳardı sizlerni anaları̀ız ḳarınlarındın (30/71a3=16:78 R)

"Tanrı sizleri annelerinizin karınlarından çıkardı."

Kadının çocuk doğurduktan sonra kazandığı yegâne adlandırmadır. Bu kelime ilk olarak Uygurcada kullanılmaya başlanmışsa da Uygurcada daha çok ög kelimesi kullanılmıştır (Li, 1999, s. 118).

Dîvânu Lugâti 't-Türk'te “anne” anlamında kullanılan çeşitli diyalektlere ait kelimeler şu şekildedir:

ebe: Oğuzcada anne. Karluk Türkmenlerinde $\operatorname{sert} b(p)$ ile. 55/41 (DLT)

Kaşgarlı'nın verdiği bilgiye göre Oğuzcada “anne” anlamına gelen ebe kelimesi, Karluk Türkmenlerinde epe şeklinde telaffuz edilmektedir (55/41 DLT).

hana: Hotanlılar ve Kençeklerin dilinde anne 27/12 (DLT)

Kaşgarlı'nın verdiği bilgiye göre Hotanlılar ve Kençeklerin dilinde “anne” anlamına gelen kelime hana'dır (27/12 DLT). Kelime başında bir $h$ - türemesi söz konusudur.

uma: Tibet dilinde anne. 59/44, 179/152 (DLT)

anaç: Bütün kavmin annesi imiş gibi akıllılık gösteren küçük kız. Bu söz ona sevgi ifade etmek için kullanılır. 38/25 (DLT)

Kelime, + +ç küçültme fonksiyonunda isimden isim yapma ekiyle oluşmuş bir sevgi ifadesi taşımaktadır ve incelenen metinlerden sadece Dîvânu Lugâti 't-Türk'te karşımıza çıkmaktadır.

kükü küküy: Teyze 547/447 (DLT)

kükü.yüm keldi (547/447 DLT)

"Teyzem geldi."

“Teyze" anlamina gelen kükü ve küküy kelimeleri incelenen metinlerde sadece Dîvânu Lugâti 't-Türk'te karşılaştığımız kelimelerdir. 
eçe: Büyük k1z kardeş 56/42 (DLT)

eke: Abla; büyük k1z kardeş 56/42, 57/44, 447/351 (DLT); 261v/3=024/061 (TİEM)

“Abla, büyük kız kardeş" anlamlarına gelen kelimeler Dîvânu Lugâti 't-Türk'te eçe ve eke, Karahanlı Türkçesi Satır Arası Kur'an Tercümesi'nde (TIEM Nüshası) eke olarak karşımıza çıkmaktadır. Kaşgarlı'nın verdiği bilgi şu şekildedir: Cim, kef'ten dönüşmüştür, germ'in cerm ve günbed'in cünbed olması gibi.

ekeç: Bütün kavmin kız kardeşi imiş gibi akıllılık gösteren küçük kız. Bu söz ona sevgi ifade etmek üzere kullanılır. 38/25 (DLT)

Anaç kelimesi gibi ekeç kelimesi de $+c ̧$ küçültme fonksiyonunda isimden isim yapma ekiyle oluşmuş bir sevgi ifadesidir. Kelime incelemeye konu olan metinleden sadece Dîvânu Lugâti t-Türk te görülmektedir (38/25 DLT).

Eke ve eçe kelimeleri Eski Türk dili devresinde de "abla” anlamında karşımıza çıkmaktadır: ög(ü)m k(a)tun ul(a)yu ögl(e)r(i)m (e)k(e)l(e)r(i)m keliñünüm kuunç(u)ylar(1)m bunca y(e)me tir(i)gi küñ bolt(a)çı (e)rti (KT K9) “(Kül Tigin olmasaydı) annem Hatun başta olmak üzere (diğer) annelerim, ablalarım, prenseslerim, bunca hayatta kalanlar cariye olacak idi, ölenler (de) yazıda yabanda yata kalacak idiniz." (Tekin, 2014, 38-39).

k(a)l(1)n k(a)d(a)ş(1)mka bökm(ä)d(i)m yeta ken(i)m eçäm [ö]gümkä bökm(ä)d(i)m buy-a. "Erkek akrabalarıma, üç akrabama, kız akrabalarıma, üç güvey, çok akrabama doyamadım, ne yazık, akrabalar, kız kardeşler, anneme doyamadım, ne acı.” (E 59, 7-8-9).

eze: Abla. Oğuzlarda ona eze adını verirler. 57/44 (DLT)

Eke ve eçe kelimeleri ile aynı anlama gelen ancak Oğuzlar arasında eze şeklinde telaffuz edilen bir kelimenin varlığını da Dîvânu Lugâti 't-Türk'ten öğreniyoruz (57/44 DLT). Kelime bugün Türkiye Türkçesi ağılarında "teyze, hala" (https://sozluk.gov.tr/) Türkmen diyalektinin Nohur Ağzında “anne, abla” (Li, 1999, s. 141) ve çağdaş Kıpçak diyalektlerinden Kırgızcada "teyze, yenge” anlamlarında yaşamaktadır (Ercilasun; Mehmedoğlu Aliyev; Şayhulov; Zadualı Kajıbek; Konkobay Uulu; Yusuf; Goklenov; Mahpir; Cecenov 1991: 2).

sinil: Erkeğin küçük kız kardeşi 230/200, 447/351, 604/496 (DLT)

Kelime Göktürk Abideleri’nde “küçük kız kardeş” anlamında geçmektedir: Siyilim kunçuyug birtimiz “Küçük kız kardeşim prensesi verdik." (K.T.D.20). Uygurcada da kelimenin manası aynıdır: Kim kayu eren ekeler siyiller kızlar analar dıntar birle yavaz iş işlep yazınsar "Erkekler, abla ve kız kardeşler ile kızlar ile analar ile ve rahipler ile kötü iş işleyip günahkâr olsalar" (Tekin, 2019 s. 155).

Dîvânu Lugâti 't-Türk'te ise kelimenin anlamı “erkeğin küçük kız kardeşi”" şeklindedir (447/351 DLT). 
Kan akrabalığına dayalı adlandırmalar incelenen metinlerde ana, kükü $\sim$ küküy, eçe, eke, eze, anaç, ekeç ve sịil şeklindedir.

\section{Sonradan Kazanılmış Adlandırmalar}

\subsection{Evliliğe Dayalı Olarak Ortaya Çıkan Adlandırmalar}

ewlüg: Hanım, eş. 169v/9=011/081, 282r/9=028/029 (TİEM)

Dîvânu Lugâti 't-Türk'te "kadın” manasına gelen ewlik ewlük kelimeleri, Karahanlı Türkçesi Satır Arası Kur 'an Tercümesi’nde (TIEEM Nüshası) “hanım, eş” anlamında karşımıza çıkmaktadır.

baldız: Kadının (eşin) küçük kız kardeşi, eşin en küçük kız kardeşi 230/200, 447/351 (DLT)

Erkeğe göre kadının kız kardeşine verilen addır. Fakat Dîvânu Lugâti 't-Türk'te kadının en küçük kız kardeşine verilen ad olduğu şeklinde bir izah bulunmaktadır (230/200 DLT).

katun "hanım, eş" 414r/8=066/005 (TİEM)

Daha önce "soya dayalı adlandırmalar” başlığında da karşımıza çıkan kelime, Göktürk Abideleri'nde "kağanın hanımı, hatun" anlamlarına gelmekte, sadece Karahanlı Türkçesi Satır Arası Kur'an Tercümesi'nde (TIEM Nüshası) ve "hanım, eş” anlamlarında görülmektedir.

hatun: "kadın, eş" 27r $/ 7=002 / 0223,120 \mathrm{r} / 8=007 / 083,175 \mathrm{v} / 4=012 / 030,177 \mathrm{v} / 5=012 / 051$, $281 \mathrm{v} / 1=028 / 009,450 \mathrm{v} / 4=111 / 004,307 \mathrm{v} / 5=033 / 030,309 \mathrm{r} / 1=033 / 053,306 \mathrm{v} / 9=033 / 028$, 439r $/ 5=085 / 010,290 \mathrm{r} / 9=029 / 033$ (TİEM)

Kelime başında bulunan $k$ sesinin $h$ sesine yerini bırakması Karahanlı Türkçesi dil devresinden itibaren görülen fonetik bir hadisedir. Hatun kelimesi "kadın, eş" anlamlarında taradığımız metinlerde sadece Karahanlı Türkçesi Satır Arası Kur'an Tercümesi’nde (TIEM Nüshası) karşımıza çıkmaktadır.

kelin: gelin 494, 2380, 3540, 3567, 3839 (KB)

Kel- fiilinden "(aileye) gelen kişi anlamında türemiş bir akrabalık adı olan kelimedir (Clauson, 1972, s. 719). Kelime Göktürk Abideleri’nde kelinün "gelinler” (<kelin+gün) şeklinde ögüm katun ulayu öglerim ekelerim keliĐünüm kunçuylarım "Annem hatun ve analarım, ablalarım, gelinlerim, prenseslerim" ibaresinde görülmektedir (K.T.K.9). Kelime Uygurcada da aynı anlamdadır: keliøünüm "gelinlerim” TT VI, 311; VII, 40, 51 (Caferoğlu 1968: 104).

kişi kirmedük ilke kirse kalı

kelin teg bolur er agin teg tili (KB 494)

"Kişi bilmediği bir memlekete girince, gelin gibi olur, dili tutulur." 


\section{kis kisi/kişi}

kis kisi: zevce 1165, 3371, 3372, 3386, 3527, 4479, 4481, 4483, 4490, 4493, 4494, 4502, 4507 (KB); 166/143, 167/144 (DLT); 91r/5=005/089, 58r/4=004/003, 58r/4=004/003 (TİEM)

Kisi kelimesi Göktürk harfli metinlerde bulunmamaktadır. Eski Uygur Türkçesinde "zevce, eş kadın, kul köle, prenses" anlamında kisi kelimesi görülmektedir (Caferoğlu, 1968, s. 112).

Kutadgu Bilig'de kisi kelimesi on üç yerde “eş, zevce” anlamında geçmektedir:

kiming bold 1 erse o $\}$ ul kız kisi

negü teg kelir ol kişining usı (KB 1165)

"Kimin karısı, oğlu ve kızı varsa, o kişi nasıl rahat uyuyabilir."

Dîvânu Lugâti 't-Türk'te kis “zevce” anlamındadır. Kaşgarl1, kelimeyi şöyle izah etmiştir: Anıり kisi "onun zevcesi”. Bazıları bunu izafetle (iyelik eki ile) kullanır. Ol kisi aldı "O, bir kadın aldı (evlendi)" (DLT 166/143).

Ceval Kaya, isi $\sim$ işi $\sim$ kisi $\sim$ kişi ve belki tişi, kelimelerinin birbirinin varyantları olabileceğini belirtir (2018: 24).

kişi: Yağmalarda zevce 4490 (Viyana Nüshas1), 4493, 4494 (Viyana ve Kahire Nüshas1), 4502 (Viyana Nüshas1); 44/445 (DLT); 7v/4=002/060, 18v/3=002/157, 42v/6=003/047, $107 \mathrm{r} / 3=006 / 122,150 \mathrm{r} / 5=009 / 107,164 \mathrm{v} / 1=011 / 017,186 \mathrm{v} / 2=013 / 033,206 \mathrm{v} / 7=017 / 011$, $211 \mathrm{rr} / 6=017 / 067,212 \mathrm{v} / 4=017 / 088,213 \mathrm{r} / 3=017 / 094,219 \mathrm{r} / 2=018 / 054,224 \mathrm{r} / 1=019 / 017$, $228 \mathrm{r} / 1=019 / 87$ (TIEM)

Göktürk Abideleri’nde “insan” anlamına gelen kişi kelimesinin Eski Uygur Türkçesinden itibaren ikinci anlam olarak "zevce, eş” anlamını kazandığı görülmektedir (Caferoğlu, 1968, s.112).

Kutadgu Bilig'in yukarıda belirtilen nüshalarında kisi ve tişi kelimesinin alternatifi olarak kişi kelimesinin kullanıldı̆̆ görülmektedir:

bularda talusin ayayın sanga

kişi alğu erse ķulaķ tut mẫga (KB 4490)

"Bunlardan hangisinin daha iyi olduğunu sana söyleyeyim; evlenmek istersen, bana kulak ver."

Kelime Dîvânu Lugâti 't-Türk'te “zevce. Yağmalarda “O erkek evlendi mi?” anlamında ol kişi aldı mu denildiğini işittim.” şeklinde açıklanmıştır (DLT 44/445).

koduz kadın; kağanın hatun dışındaki eşleri. 
Dîvânu Lugâti 't-Türk'te “eşi vefat etmiş kadın” anlamında koḍz, tuğsak, tul, tul tuğsak kelimeleri geçmektedir. Koduz kelimesi Göktürk Abideleri’nde şu şekilde geçmektedir.

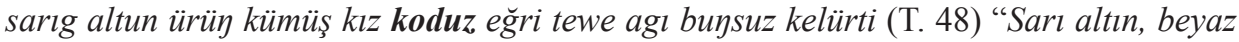
gümüş, kızlar (ve) karılar, (tek) hörgüçlü develer, ipeklileri sıkıntısızca getirdiler.” (Aydın, 2021, s. 187).

yılkısın barımın kızın koduzın kelürtüm (Ş.U. D. 3) "At sürülerini, varlıklarını, kızlarını ve karlarını getirdim." (Aydın, 2018, s. 55)

Koduz kelimesinin etimolojisi ve anlamı üzerine çeşitli görüşler mevcuttur. ${ }^{2}$ Hacer Tokyürek kelimeyi ‘dul kadın’ olarak anlamlandırıp “muhtemelen savaş sırasında eşleri ölen kadınları ifade ettiğgi”ni söylemiştir (Tokyürek, 2013, s. 126).

Erhan Aydın, kelimenin Kâşgarlı' dan hareketle “dul” olarak anlamlandırılmasını doğru bulmaz ve kelimeyi 'kağanın hatun dışındaki diğer eş(ler)i' olarak anlamlandırır (Aydın, 2018, s. 148).

Fikret Turan, V. Thomsen, T. Tekin ve M. Ergin tarafindan "kadın”, G. Giraud tarafindan “dul” ve O. F. Sertkaya tarafından "dişi sığır” olarak anlamlandırılan kelimenin Orta Çağ toplumlarında mali varlık ve servet olarak değerlendirilen köle ve cariye bağlamında düşünülmesi gerektiğini belirtir. Turan ayrıca kelimeyi kuduz şeklinde imla etmiştir (Turan, 2020, s.292).

ḳunçuy: Kadin, eş. 29r/8=002/234, 59r $/ 3=004 / 011,60 \mathrm{r} / 2=004 / 015,60 \mathrm{v} / 2=004 / 019$, $62 \mathrm{v} / 6=004 / 034,73 \mathrm{v} / 7=004 / 129,79 \mathrm{r} / 4=004 / 176,175 \mathrm{v} / 4=012 / 30,307 \mathrm{r} / 3=033 / 037$ (TİEM)

Çinceden alınan kunçuy "eş, kadın” anlamlarında yazıtlarda en çok geçen kelimelerden biridir: esiz elime, $\boldsymbol{k}$ unçuyıma, oglanıma, bodunıma, esizme, altmış yaşımda adırıltım "Değerli devletimden, eşimden, oğullarımdan, halkımdan, kıymetlilerimden altmış yaşımda ayrıldım" (E 1, 1), kuydaki kunçuyımga adırıltım "Evdeki eşimden ayrıldım” (E 6, 4).

Kelime "kadın, eş” anlamında sadece Karahanlı Türkçesi Satır Arası Kur'an Tercümesi’nde (TIEM Nüshası) görülmektedir.

uragut: Kar1, zevce 81/71, 88/79, 99/91, 99/92, 109/99, 130/114, 131/115, 132/116, 133/116, $134 / 117,140 / 123,153 / 132,157 / 136,158 / 137,254 / 223,268 / 235,295 / 248,309 / 254,322 / 262$, $329 / 267,331 / 268,338 / 273,340 / 275,342 / 276,344 / 277,345 / 278,383 / 301,386 / 302,393 / 307$, $399 / 310,405 / 315,416 / 327,417 / 328,419 / 328,429 / 336,440 / 334,460 / 364,466 / 370,469 / 375$, 471/377, 480/384, 482/386, 495/397, 497/398, 501/402, 526/427, 534/335, 535/435, 578/476, $617 / 513$ (DLT); 31/5a3=19:5, 31/6a3=19:8, 38/96b1-2=66:10 (R)

Men ḳorḳar men yag̉uḳlarımdın ménde kị̣in, erür menị urag்utum ḳısır (31/5a3=19:5 R)

2 Detaylı bilgi için bkz. (Erhan Aydın, Uygur Yazıtları, İstanbul: Bilge Kültür Sanat, 2018). 


\section{"Ben kendimden sonraki soyumdan benim eşim kısırdır diye korkarım."}

emiglig ura.gut küse.gçi bolu.r (88/79 DLT).

\section{"Emzikli kadın iştahlı olur."}

Uragut kelimesi, genel "dişi, kadın, kız" anlamlarının dışında "karı, zevce" anlamıyla Dîvânu Lugâti 't-Türk'te ve Türkçe Illk Kur'an Tercümesi'nde (Rylands Nüshası) karşımıza çıkmaktadır.

İncelediğimiz metinlerde $u r a g u t^{3}$ kelimesinin "karı, zevce; kadın, kız; dişi”" anlamlarıyla karşılaştık. Kelimenin kökeni hakkında bir görüş birliği bulunmadığı görülmektedir. Clauson, uragut kelimesinin Eski Türkçede çok sınırlı bir zaman diliminde kadın için kullanılan ortak bir kelime olduğunu belirtir. Tiş̧i “dişi”” kelimesinden daha belirgin bir şekilde kadını karşıladığını söyler. Kelimenin morfolojik olarak fiillerden isim türeten - gut eki ile türetildiğini belirten Clauson ura- kökünün anlamına değinmez (1972, s. 218). Clauson ayrıca avrat kelimesinin kökenini uragut'a bağlamak için kuvvetli deliller olduğunu ifade eder. Bu bağlamda Clauson, Rabguzî'nin Kısasü'l-Enbiyâsı'nın eski nüshalarında geçtiğini söylediği urawut şeklini delil olarak göstermektedir (1972, s. 218). Tenişev uragut'u ura- "şişmek", ur "ur, şişlik", mecazen "hamile" kelimesiyle ilişkilendirir (2001: 315). Räsänen ise kelimenin türediği ekle ilgili olarak bilgi vermemiş, kökü Moğolca ur-ug'a bağlamıştır (1969, s. 515). Saadet Çağatay’ın görüşü, kelimenin "soy, tohum" manasına gelen urug ile ilişkili olduğu yönündedir (Çağatay, 1962: s.19). Bazı araştırmacılar bugün kullanılan “avrat” kelimesinin "uragut” tan gelişmiş bir şekil olduğunu ileri sürmüş (uragut> uravut> uravat> urvat $>$ arvat), diğer bir kesim ise Arapça “avret”" kelimesinden türediğini iddia etmişlerdir (Güner, 2013, s.2659; Erdoğan, 2016, s. 200).

yenge: Ağabeyin zevcesi, yenge 610/503 (DLT)

Clauson "Babanın küçük erkek kardeşinin karısı; ağabeyin karısı" şeklinde izah eder (1972:950). Kelime Eski Uygur Türkçesinde de yenge veya yeyge şeklinde geçmektedir (Caferoğlu, 1968, s. 293).

Karahanlı Türkçesi metinlerinde evlilik yoluyla kazanılan kadınların kazandığı adlandırmalar da onların toplumsal hayatın içindeki durumlarının bir göstergesi olarak karşımıza çıkmaktadır. Bu bağlamda kadının eş olması anlamında äwlüg, hatun katun, kis kisi, kişi, kunçuy ve uragut kelimeleri görülmektedir. Evlenen kadının evlendiği aile içerisindeki adlandırılışı gelin şeklindedir. Bu kelime de metinlerde kelin kelimesiyle karşılanmaktadır. Kadının küçük kız kardeşi baldız, ağabeyin eşi ise yenge şeklinde adlandırılmıştır.

Bu başlık altında sütanne kavramını da ele alıp incelemek mümkündür. Zira evlenen kadının bir vesileyle çocuğunu emzirmek üzere başka bir anneye vermesi sonucu ortaya çıkan bu kavram incelenen eserlerde şöyle karşımıza çıkmaktadır:

3 Detaylı bilgi için bkz. (Nurhan Güner, "Kadınla İlgili Eski Türkçe Bir Kelime: Uragut”, Turkish Studies Dergisi, C. 8 , S. 9, 2013, s. 2569-2669) 
ämgü: Sütannesi 281v/5=028/012 (TİEM)

awurta avurta: Sütanne 339/274 (DLT); 4505 (KB)

avurtası eđgü kişi tut arı̀g

og̉ul ķız arı่̀ ķopga turg̉ay ķarıg (KB 4505)

"Sütninesi olarak iyi ve temiz bir kadın tut; oğlun kızın temiz büyür ve uzun ömürlü olur."

ol awurta tutund1 (339/274 DLT)

"O, sütanne edindi."

“Sütanne, sütnine” anlamına gelen kelimeler ämgü ve awurta kelimeleridir. Ämgü kelimesi äm- fiil kökünden - gü fiilden isim yapma ekiyle oluşmuştur. Awurta kelimesi için Clauson "ebe, sütnine" anlamındadır demektedir ve bu kelimenin Farsça kökenli olabileceği görüşündedir (1972, s. 15)

Yine bu başlık altında değerlendirebileceğimiz bir başka konu evlenen kadının eşinin vefat etmesi sonrasında kazandığı "dul” anlamına gelen adlandırmalardır:

\section{tul/tuġsak/tul tuġsak:}

İncelenen metinlerden Dîvânu Lugâti 't-Türk'te “dul kadın” için tul, tuğsak ve tul tugssak kelimeleri kullanılmıştır. Ayrıca yukarıda belirtildiği üzere koduz kelimesi de eserde yine "dul kadın" anlamındadır.

tuğsak: Dul kadın 236/205, 236/205 (DLT)

tul: Dul 501/402 (DLT)

tul tugsak: Dul kadın 236/205 (DLT)

\subsection{Sosyal Sinıflar}

İncelenen metinlerde kadınların sosyal yaşamları içerisindeki durumlarının bir göstergesi olarak ortaya çıkan adlandırmaları şu şekildedir:

ās: Cariyelere verilen ad. 53/38 (DLT)

kara-baş: Erkek veya dişi köle 543/443 (DLT); Cariye 298 (AH)

Dîvânu Lugâti 't-Türk’te “erkek veya dişi köle", Atebetü'l Hakayık'ta "cariye" anlamında görülen kelime, F. Turan’a göre başını örtmek ve kapanmak zorunda olmayan genç köle kız anlamından mecaz yoluyla oluşmuş olmalıdır (Turan 2020, s. 294). 


\section{kırkın/kapaklığ kırkın/yinçge kapaklıg}

Kelime incelenen metinlerden sadece Dîvânu Lugâti 't-Türk'te "cariye ve genç kız" anlamlarıyla karşımıza çıkmaktadır:

$$
\text { ḳırkın: : Kız, cariye 164/142, 323/263 (DLT) }
$$

ḳapaklıg ḳırḳın: cariye. I, 326-8.

yinçke ḳapaḳlıg: yetişkin cariye. I, 326-12.

kiz/ kız: cariye 5/3, 157/136, 164/142, 192/164, 208/178, 402/313, 404/314

küng: cariye. II, 82-18, 248-18; III, 318-11

Eski Türklerde kölelik, cariyelik kurumları konusunda bilgi alabileceğimiz yegâne kaynak Göktürk Abideleri'dir. Nitekim abidelerde "kul" ve "câriye" kelimelerine rastlanmaktadır: Tabgaç budunka beglik urı oglın $\boldsymbol{k} u \boldsymbol{u}$ boltı, eşilik kız oglın küng boltı. "Türk halkı - bey olacak erkek evladın kul oldu, hanımefendi olacak kız evladın cariye oldu” denmektedir (K.T.D.7)

Uygurlar döneminde ise köle satış belgelerinden bu kurumun varlığını kesin olarak anlaşılmaktadır. Bu belgelerden anlaşıldığına göre kadın ve çocuklar, borçlanmadan dolayı köle durumuna düşebildikleri gibi para ve mal karşılığında da satılabilmektedir (Parlatır, 1983, s. 810).

Türklerin İslamiyet'i kabul ettikleri dönemden itibaren bu sosyal sınıf ile alakalı olarak karşımıza çıkan terminoloji oldukça teferruatlıdır. "Cariye" karşılığında kullanılan kelimeler ās, kara-baş, kırkın, kapaklı̆̆ kırkın, kiz/ kız küđg, yinçke kapaklı̆̆ şeklindedir.

egetlig: Hizmetçisi olan gelin 86/78 (DLT)

Bir statü göstergesi olarak karşımıza çıkan egetlig kelimesi sadece Dîvânu Lugâti 't-Türk’te geçmektedir (86/78 DLT).

\section{iget egetlik kara-baş:}

egetlik kara-baş: Zifaf gecesinde gelinle gönderilen hizmetçi.86/78, 87/78 (DLT)

iget: Gerdek gecesinde gelinle beraber, ona hizmet maksadıyla gönderilen hizmetçi 37/24 (DLT)

mamu: Gerdek gecesi gelinle gönderilen kadının adı. Asli bir kelime değildir.549/449 (DLT)

Egetlik kara-baş, iget ve mamu kelimeleri Dîvânu Lugâti 't-Türk'te geçen sosyal sınıf göstergeleri olarak karşımıza çıkmaktadır.

küni: kuma. 549/449 (DLT) 
Göktürk Abideleri’nde küni kelimesi “kıskançlık, hasetlik” anlamındadır. (B.K.D.30)

Kaşgarl1, Dîvânu Lugâti 't-Türk'te bu kelimeyi bir atasözüyle örneklendirir: Künini门 külü. ne tegü yag1 "Kuma o derece düşmandır ki aradaki bütün düşmanlıktan dolayl, külü diğerinin gözüne savrulur (549/449 (DLT)

Toplum içerisinde sosyal bir sınıf göstergesi olan cariyelik, hizmetçi sahibi olmak, kumalık

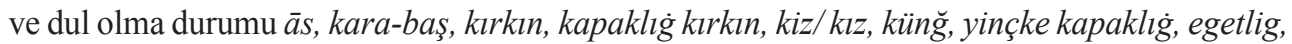
egetlik kara-baş, mamu, küni, kelimeleriyle karşımıza çıkmaktadır.

\subsection{Unvanlar, Rütbeler}

İncelenen metinlerde kadınların genellikle kağanlarla yaptıkları evlilikler neticesinde kazandıkları unvan ve rütbeler şu şekildedir:

altun tarım: Hanım sultanlara verilen unvan 199/171 (DLT)

\section{kunçuy/katun kunçuy:}

kunçuy: Kadınların soylu, hatundan bir derece aşağı olanı 50/451 (DLT).

katun kunçuy: Hatundan bir derece aşağı olan soylu kadın 550/451 (DLT)

Hatun'dan bir derece aşağıda bulunan kadın, bige, prenses. Buradan alınarak "katun kunçay" denir. Devlet idaresinde hak sahibi olan hükümdarın hanımları, kızları, hanedanı mensup prenseslere denir (Genç, 1981, s. 83). Eski Türkçede ve Kaşgarlı da bu söze "prenses" anlamında da rastlamaktayız (Temir, 1972, s. 198).

terken: kadınlara ait bir unvan 109, 115, 121 (KB); 188/161, 222/191 (DLT);

Arat, Yusuf Has Hacib'in bu kelimeyi "hükümdarlık yetkisiyle" ilişkilendirdiğini belirtir (1979, s. 27-29). R. Genç, “Terken” adlı makalesinde; "başlangıçta yalnız hükümdarlar için kullanılırken, sonradan Osmanlılardaki sultan unvanı gibi, hatunlara da verilmiştir” der (1982, s. 116).

Kutadgu Bilig'de üç yerde karşımıza çıkan bu unvan, Dizin'de "kadınlara ait bir unvan" olarak karşılanmaktadır. Ancak kelimenin üç beyitte de "devletli, haşmetli" anlamlarında kullanıldığı görülmektedir:

bayat birdi devlet ay terken kut1

anıng şükri kılġu okıp ming atı (KB 109)

"Ey devletli hükümdar, Tanrı sana saadet verdi; adını bin kere zikrederek ona şükür lazımdır."

Kaşgarlı Mahmud, Dîvânu Lugâti 't-Türk'te tengri kelimesini açıklarken, tengriken terimine değinmektedir. Kaşgarlı, "gayr-i Müslim Türklerin bilgin kimseye tengriken dediklerini”" 
belirtir (Atalay, 1988, s. 377). Ayrıca Kaşgarlı Mahmud, terken kelimesi hakkında da izahatta bulunurken; "Karahanlılarda bir bölgeye hükmeden hana hitap şekli. Karahanlılar sülalesine mensup olmayanlara ve han olmayanlara bu şekilde hitap edilmez. Ey kendine itaat edilen anlamına gelir" der (Ercilasun-Akkoyunlu, 2018, s. 191). Ancak eserde zaman zaman terken kelimesini "sultan” biçiminde açıklar (Atalay, 1988 I, s. 376; 441-442; II: 209):

Terken Katun kutına tegür mindin koşug

aygıl sizin tapugçı ötnür yạı tapug

“Diyor ki: Sultan Hatun'a benden bir kaside götür ve "kulunuz size yeni bir hizmetle armăgan ediliyor" de."

Kadınların sahip oldukları unvanlar ve rütbeler şu şekildedir: Altun tarım, kunçuy, katun kunçuy ve terken. Bu unvanlar, kadınların devlet kademesinde sahip oldukları statünün birer göstergesidir.

\subsection{Ahlakî Bakımdan Düşkünlük Gösteren Kadın Adlandırmaları}

İncelemeye konu olan eserlerden özellikle Dîvânu Lugâti 't-Türk'te karşılaşılan adlandırmalar şu şekildedir:

\section{ekek işler/ersek/ersek işler:}

ekek işler: fahişe kadın 52/37 (DLT)

ersek: erkek isteyen, fahişe 64/51, 295/248 (DLT)

ersek işler: fahişe kadın 64/51 (DLT)

oynaş: -haram olarak- başkasıyla birlikte olan kadın 73/59 (DLT)

Bu kadınların bu düşkünlüğün içine kendi iradeleriyle mi yoksa iradeleri dışında mı düştüklerinin bir açıklaması bulunmamaktadır.

\subsection{Bedenen ve Ruhen Temiz Olan Kadın Adlandırmaları}

ertini özük: Vücudu inci gibi pürüzsüz olana kadın 48/33, 82/72 (DLT)

altun özük: özü som altın gibi temiz olan, altın gibi temiz ruhlu kadın. 48/33 (DLT)

Bedenen ve ruhen temiz olan kadınların da altın, inci gibi kıymetli nesnelerle nitelendirildiği anlaşılmaktadır. 


\section{SONUÇ}

Kadın toplumsal cinsiyet bağlamında incelenmiş, çeşitli cephelerden kadın için yapılan adlandırmalar belirlenmiştir. Bu bağlamda yapılan taramalar sonucu toplam kırk dört (44) kelime tespit edilmiştir.

Doğuştan gelen durumları çerçevesinde kadınlar cinsiyet, yaş, soy ve kan akrabalığı bakımından farklı kelimelerle adlandırılmışlardır. Kadınların kendi müdahaleleri dışında, kendilerinden bağımsız olarak gelişen bu kavram alanları Karahanlı Türkçesi metinlerinde şu şekilde tespit edilmiştir: "Kadın” kelimesi karşılığında işi iş̧ler eşler eşiler, ewlik ewlük, kız, tişi, tişilig, uragut kelimelerinin kullanıldığı görülmüştür. Özellikle ewçi, ewlik ewlük kelimeleri, kadının ev işlerindeki temel rollerini göstermektedir. Evlenmemiş kızlar için kullanılan adlandırmalar ev klzı, kapaglıg klz, yinçge kız şeklindedir. Buradan kızların bekâr olma durumlarının sadece kız kelimesiyle değil farklı kelimelerle de anlatılmaya çalışıldığı görülmektedir.

Cinsiyete dayalı adlandırmaların bulunduğu ifadeler incelendiğinde, zaman zaman bu ifadelerin mecazen veyahut benzetme amaçlı kullanıldığı tespit edilmiştir. Örneğin Kutadgu Bilig'de dünyanın "kız" gibi bir edası olması, sözünde durmayan kişinin ancak "kadın" olabileceği gibi ifadelere rastlanmıştır.

Toplumda yaşa dayalı adlandırmalarda açı ve kurtga kelimelerine rastlanmaktadır. Soya dayalı adlandırmalar tarım, katun, oglagu katun şeklindedir. Kan akrabalığı bağlamında "anne" anlamında ana, ebe, hana, uma kelimeleri tespit edilmiştir. "Teyze” anlamında kükü ve küküy kelimeleri görülmüştür. "Abla” anlamında eçe, eke, eze kelimelerine tesadüf edilmiştir. "Küçük kız kardeş" anlamında siyil kelimesi kullanılmıştır.

Kadınların evlilik, sosyal sınıflar, unvanlar ve rütbeler, ahlaki göstergeler, ruh ve beden temizliği gibi durumlarına dayalı olarak sonradan kazandıkları adlandırmaları onların sosyal ve siyasî hayatın içinde yer aldıkları bu alanların göstergeleri olmuştur: Ewlük, baldız, katun, altun tarım, terken, ekek işler/ersek/ersek işler, altun özük gibi kelimeler bu noktada karşılaş1lan kelimelerdir.

Bazı kelimelerin zamanla anlam geniş̧lemesine uğradığı saptanmıştır. Bu kelimeler, katun, kunçuy ve koduz kelimeleridir. Katun kelimesi hem bir unvan hem de "eş, hanım" anlamında görülmektedir. Eski Türkçede sadece "kağanın eşi”" anlamında yani bir unvan olarak kullanılırken, Karahanlı Türkçesi ile yazılmış eserlerde buna "hanım, eş" anlamı da eklenmiştir. Eski Türkçe metinlerde sadece "eş, zevce” anlamında karşımıza çıkan Çinceden alıntılanan kunçuy kelimesi de taradığımız metinlerde hem unvan hem de "kadın, eş" anlamıyla kullanılmıştır. Koduz kelimesi hem "kadın; kağanın hatun dışındaki eşleri” hem de "dul kadın” anlamında tespit edilmişstir.

Belirlediğimiz hemen hemen her madde başında belki bugün tespit edemediğimiz küçük anlam farklarını da ihtiva eden birçok kelime kullanılması; bir bakıma kadının toplumdaki 
yerinin ve öneminin de göstergesi olmuştur. Metinlerde her ne kadar zaman zaman kadını yeren ifadelere rastlanmışsa da görülüyor ki sözü edilen dönemde kadın toplumun içindedir. Kelime kadrosunun zengin oluşu, ifade edilmek istenen durum, duygu ve düşüncelerin de zengin olduğunun kanıtıdır.

Hakem Değerlendirmesi: Dış bağımsız.

Çıkar Çatışması: Yazar çıkar çatışması bildirmemiştir.

Finansal Destek: Yazar bu çalışma için finansal destek almadığını beyan etmiştir.

Peer-review: Externally peer-reviewed.

Conflict of Interest: The author has no conflict of interest to declare.

Grant Support: The author declared that this study has received no financial support.

\section{KAYNAKÇA/REFERENCES}

Arat, R. R. (2005). Yusuf Has Hacib, Kutadgu Bilig. İstanbul: Kabalcı Yayınevi.

Arat, R. R. (2006). Atebetü'l-Hakayık. Ankara: Türk Dil Kurumu Yayınları.

Argunşah, M. (2017). Türkiye Türkçesindeki Kadınla İlgili Temel Söz Varlığının Tarihî Gelişimi, Uluslararası Türk Dili ve Edebiyatında “Kadın” Sempozyumu. Amasya Üniversitesi, 81-105.

Ata, A. (2004). Türkçe Illk Kur'an Tercümesi (Rylands Nushası). Ankara: Türk Dil Kurumu Yayınları.

Atalay, B. (1999). Dîvânu Lugâti 't-Türk Dizini. Ankara: Türk Dil Kurumu Yayınlar1.

Aydın, E. (2018). Uygur Yazıtları, İstanbul: Bilge Kültür Sanat Yayıncılık.

Aydın, E. (2019). Sibirya'da Türk İzleri Yenisey Yazıtları. İstanbul: Kronik Kitap.

Aydın, E. (2020). Türklerin Bilge Atası Tonyukuk, 4. bs., İstanbul: Kronik Kitap.

Bayat, F. (2008). Orta Türkçe Sözlük. İstanbul: Yalın Yayıncılık.

Caferoğlu, A. (1968). Eski Uygur Türkçesi Sözlüğ̈̈. Ankara: Türk Dil Kurumu Yayınlar1.

Clauson, Sir G. (1972). An Etymological Dictionary of Pre-Thirteenth Century Turkish. Oxford: At the Clarendon Press.

Çağatay, S. (1962). “Türkçede Kadın İçin Kullanılan Sözler”, Türk Dili Araştırmaları Yıllı̆̆ı-Belleten, c. $10,13-49$.

Çağatay, S. (1978). Türk Lehçeleri Üzerine Denemeler, Ankara: Ankara Üniversitesi Basımevi.

Dankoff, R. \& James, K. (1982), Maḥmūd al-Kāşgarī, Compendium of the Turkic Dialects (Dīwān Lugat at-Turk), Part I, Harvard University Press, USA.

Debreli, Z. G. (2016). “Kutadgu Bilig'de Kadın”, Studies Of The Ottoman Domain 6-11.

Demir, E. (2021). “Kutadgu Bilig’de İnşa Edilen Kadın Kimliği Üzerine Sosyal Bir İnceleme”. Korkut Ata Türkiyat Araştırmalarl Dergisi, 4 (Nisan/April 2021), 199-208.

Donuk, A. (1988). İdari-Askeri Ünvan ve Terimler, İstanbul: Türk Dünyası Araştırma Vakfı,

Ercilasun, A. B. \& Akkoyunlu, Z. (2018). Dîvânu Lugâti 't-Türk (Giriş-Metin-Çeviri-Notlar-Dizin). Ankara: Türk Dil Kurumu Yayınları. 
Ercilasun, A. B. \& Aliyev, A. M. \& Şayhulov, A. \& Kajıbek, E. Z. \& Konkobay Uulu, K. \& Berdak, Y. \& Göklenov C. \& Mahpir, V. U. \& Çeçenov, A. (1991). Karşılaştırmalı Türk Lehçeleri Sözlüğü I. Ankara: Kultur Bakanlığı Yayınları.

Erdoğan, İ. (2016). “Dîvânu Lugâti’t-Türk’te Kadınla İlgili Kavramlar”, Dini Araştırmalar Kadın Özel Sayısı, 2016, 197-207.

Ergin, M. (2000). Orhun Abideleri. İstanbul: Boğaziçi Yayınları.

Genç, R. (1981). Karahanlı Devlet Teşkilâtı. Ankara: Kültür Bakanlığı Yayınları.

Genç, R. (1997). Kaşgarlı Mahmud'a Göre XI. Yüzyılda Türk Dünyası, Ankara Üniversitesi Basımevi, Türk Kültürünü Araştırma Enstitüsü Yayınları, Ankara.

Gömeç, S. (2009). Kök Türk Tarihi, Ankara: Akçă̆ Yayınları.

Gülensoy, T. (2007). Türkiye Türkçesindeki Türkçe Sözcüklerin Köken Bilgisi Sözlüğü, Ankara: Türk Dil Kurumu Yayınları.

Güner, N. (2013). “Kadınla İlgili Eski Türkçe Bir Kelime: Uragut.” Turkish Studies Dergisi, C. 8, S. 9, 2569-2669.

Gürbüz, E. (2020). “Türkiye'de Yapılan Çalışmalarda Orhon Yazıtları'nı Okuma ve Yorumlama Farklılıkları”. Yayımlanmamış Yüksek Lisans Tezi. İstanbul: Yıldız Teknik Üniversitesi Sosyal Bilimler Enstitüsü.

Kafesoğlu, İ. (1977). Türk Milli Kültürü. İstanbul: Ötüken Neşriyat.

Karahan, A. (2006). “Tarihî Türk Dilinin Söz Varlığına Katkılar: Kadınla İlgili Kelimeler Üzerine”. Bilkent Üniversitesi l. Uluslararası Büyük Türk Dili Kurultayı Bildirileri. Ankara.

Karahan, A. (2006). “Tarihî Türk Dilinin Söz Varlığına Katkılar: Kadınla İlgili Kelimeler Üzerine”, Bilkent Üniversitesi 1. Uluslararası Büyük Türk Dili Kurultayı Bildirileri. Ankara.

Karamanlığlu, A. F. (1966). “Silik Sözü Üzerine”. Reşid Rahmeti Arat İçin. (320- 322). Ankara.

Kaya, C. (2020). "Köktürkçede İsi/İşi Kisi/Kişi Üzerine". Ardahan Üniversitesi Insani Bilimler ve Edebiyat Fakültesi Dergisi (Belgü), 19-26.

Kök, A. (2004). “Karahanlı Türkçesi Satır Arası Kur'an Tercümesi, TİEM 73 1v-235v/2 Giriş - İnceleme - Metin- Dizin”. Basılmamış Doktora Tezi. Ankara: Hacettepe Üniversitesi.

Li, Y. S. (1999). Türk Dillerinde Akrabalık Adları. İstanbul: Simurg Yayınları.

Özdarıcı, Ö. (2011). "Dîvânü Lûgat-it-Türk’te Kadın ve Kadına İlişkin Unsurlar.” Kırıkkale Üniversitesi Sosyal Bilimler Dergisi, 1(1), 127-156.

Parlatır, İ. (1983). “Türk Sosyal Hayatında Kölelik”. Türk Dili Araştırmaları Yıllı̆̆ı Belleten, Cilt XLVIII, Say1 187, 805-829.

Räsänen, M. (1969). Versuch eines Etymologischen Wörterbuchs der Türksprachen. Helsinki: SuomalaisUgrilainen Seura.

Röhrborn, K. (2019). "Tekrar Eski Türkçe bäg eşi”. Çev. G. Aris. International Journal of Old Uyghur Studies, 1(1). 89-94.

Taşağıl, A. (2017). Kök Tengri’nin Çocukları, İstanbul: Bilge Kültür Sanat.

Tekin, Ş. (2019). Uygurca Metinler II Maytrısimit (Burkancıların Mehdisi Mmaitreya İle Buluşma Uygurca Íptidẩ Bir Dram), Ankara: Türk Dil Kurumu Yayınları.

Tekin, T. (2014). Orhon Yazıtları, 5. bs., Ankara: Türk Dil Kurumu Yayınları.

Tellioğlu, İ. (2006). “İslam Öncesi Türk Toplumunda Kadının Konumu Üzerine.” A. Ü. Türkiyat Araştırmaları Enstitüsü Dergisi [TAED], 55, 209-224. 
Temir, A. (1972).“Türk-Moğol İmparatorluğu Devrinde Sosyal ve Askeri Teşkilat”, Türk Kültürü, Yı1. X, S.118, 190-202.

Tokyürek, H. (2013). "Runik Türk Yazıtlarında ve Eski Uygur Metinlerinde Kadın Hiyerarşisi”, Türk Dili Araştırmaları Yıllığı - Belleten 2013, Cilt 61, Sayı 1, Ankara: Türk Dil Kurumu Yayınları, s. 119-130.

Turan, F. (2008-2009). Dîvânü Lûgat-it-Türk'ün Metodolojisi Üzerine.” Akademik Araştırmalar Dergisi, Say1 39, 118-130.

(2020). “Türkçede Cariyelik ve Kadın Köleliğine Dair Leksikolojik Yapılar I: Eski ve Orta Türkçe Metinlerindeki Veriler.” Uluslararası Tonyukuk Sempozyumu, 289-297.

Useev, N. (2012). "Köktürk Harfli Yenisey Yazıtlarındaki Kadını Bildiren Kelimelerin Anlamına Göre Eski Türklerde Kadın İmajı”, Dil Araştırmaları, Sayı: 11 Güz 2012, 57-66.

Ünlü, S. (2004). “Karahanlı Türkçesi Satır Arası Kur'an Tercümesi, TİEM 73 235v/3-450r/7 Giriş-Metinİnceleme-Analitik Dizin”. Basılmamış Doktora Tezi. Ankara: Hacettepe Üniversitesi.

Zieme, P. (2013). “Eski Türkçe Eş/Hanım Kelimesi Üzerine Bazı Açıklamalar”, Çev. Aybüke Betül Kiymaz, Türkbilig, 129-133.

\section{İnternet Kaynakları}

https://sozluk.gov.tr/

\section{Kisaltmalar}

KB: Kutadgu Bilig

DLT: Dîvânu Lugâti’t-Türk

AH: Atebetü'l Hakayık

R.: Rylands Nushası

TİEM: Türk ve İslam Eserleri Müzesi

B.K.: Bilge Kağan

T. Tonyukuk

K.T.: Kül Tigin

D.: Doğu Yüzü

E 100: Ortaa Tey

E 109: Uyuk-Oorzak I

TT: Türkische Turfan-Texte 